\title{
Epistemic Community and Military Reform in Indonesia
}

\author{
Broto Wardoyo \\ Department of International Relations, University of Indonesia/International Doctoral Program in Asia- \\ Pacific Studies (IDAS), National Chengchi University \\ broto09@ui.ac.id
}

\begin{abstract}
Following the fall of Suharto in 1998, Indonesia engaged in a democratization process, and as part of it, the Indonesian military (currently known as Tentara Nasional Indonesia, TNI) which during Suharto era played omnipresent roles in public affairs was forced to adopt reform agendas to disengage itself from politics. Nearly two decades since the military reform was initiated; it has been, to a certain degree, successful in establishing civilian control over the military, despite several leftovers that need to be seriously addressed. Previous studies on military reform in Indonesia have pointed out the role of the armed forces and their interests in enabling and directing the reform. Others focus on the role of civilian groups, such as the parliament, political parties, or nongovernmental organizations (NGOs). Limited attention is given to the role of academics or epistemic community in the reform. This paper argues that epistemic community plays an influential role in both processes, especially in establishing the required regulations to ensure civilian control over the military. It has the capability of maintaining their alliance with NGOs to put pressures on the implementation of reform project, while at the same time enhancing their links to the defense establishment, government, and the parliament to influence the making of the policy. The main problem in acknowledging their role lays in difficulty in identifying who the members of this community are. This paper explores not only who can be defined as the epistemic community in defense studies in Indonesia but also how this group manages to steer the direction of the reform.
\end{abstract}

Keywords - epistemic community in defense studies, military reform, democratization, Indonesia post-Suharto.

\section{INTRODUCTION}

Following the fall of Suharto in 1998, Indonesia engaged in a democratization process, and as part of it, the Indonesian military (currently known as Tentara Nasional Indonesia, TNI) which during Suharto era played omnipresent roles in public affairs ${ }^{1}$ was forced to adopt reform agendas to disengage itself from politics. The reform was aiming at establishing democratic control over the military by creating regulations to place them under the civilian supervision and to curtail their independence to seek financial support on their own. Nearly two decades since the military reform was initiated; it has been, to a certain

\footnotetext{
${ }^{1}$ These roles were possible due to the doctrine of dual function, in which the military was not only assigned with defending the country from external threat but also maintaining internal security. For a concise explanation on the doctrine of dual function, see Jenkins (1983) and Said (1987).
}

degree, successful in establishing civilian control over the military, despite several leftovers that need to be seriously addressed.

Previous study on military reform in Indonesia has pointed out the role of the armed forces and their interests in enabling and in directing the reform. Others focus on the role of civilian groups, such as the parliament, political parties, or non-governmental organizations (NGOs). Limited attention is given to the role of academics or epistemic community in the reform. ${ }^{2}$ This paper focuses on the role of epistemic community in defense studies in Indonesia and its network in advocating and advancing the military reform in Indonesia. ${ }^{3}$ This paper argues that epistemic community plays an influential role in both processes, especially in establishing the required regulations to ensure civilian control over the military. It has a capability of maintaining their alliance with NGOs to put pressures on the implementation of reform project while at the same time enhancing their links to the defense establishment, government, and the parliament to influence the making of the policy. This paper will be divided into three parts. The next part discusses the framework of the epistemic community, followed by an examination the role of epistemic community in Indonesia's military reform. The final section is the conclusion.

\section{THE CONCEPT OF EPISTEMIC COMMUNITY}

The military reform in Indonesia has quite often been depicted as an internal reform. ${ }^{4}$ However, the progress of

\footnotetext{
${ }^{2}$ While the works of Sukma, Muna, Scarpello, and Lay also discuss the role of academics, they frame the role of these academics within the role of NGOs instead of epistemic community.

${ }^{3}$ This paper focuses at national-level and therefore does not examine what has happened in local context. At local level, NGOs usually play the dominant role in advocating and advancing the reform instead of academics.

${ }^{4}$ In 1998, the military headquarter held a seminar to redefine military’s role in changing political circumstances which produced the so called "New Paradigm.” It pointed out several key agendas to reposition the military in Indonesia's politics which included: separation of the police force from military's chain of command, liquidations of the armed forces sociopolitical roles, withdrawal of military representatives from both national and regional legislatures, restrictions for active military officers to hold civilian bureaucratic positions, neutrality during national elections, and the changing characteristic of relationship between the armed forces and retired officers organizations (TNI Headquarter,1998, 2001).
} 
the reform is also subject to other actors' contributions, including the epistemic community. The term epistemic community itself can be defined as "a network of professionals with recognized expertise and competence in particular domain and authoritative claim to policy-relevant knowledge within that domain or issue-area.” Simply put, it is a group of academics working on a particular issue. Their role in the decision-making process is somehow distant and usually limited to diffusing knowledge to decision makers so that the latter would be able to take the best policy based on sound rationales. ${ }^{5}$ Also, the epistemic community usually is regarded as a neutral actor ${ }^{6}$ and therefore tends to be accepted by different parties, including bureaucrats and NGOs.

In their work, epistemic community needs to establish a network with decision makers to successfully influence a policy and create a system with like-minded groups to spread ideas such as with NGOs. In the issue of Security Sector Reform (SSR), the epistemic community has been able to play an influential role in spreading the idea of security governance, such as the one in post-Communist Eastern Europe. Their primary function in the spread of SSR ideas is more on creating consensus on the new way to address security concerns through security governance that leads to the creation of policies based on democratic principles.

\section{THE ROLE OF EPISTEMIC COMMUNITY IN MILITARY REFORM IN INDONESIA}

Identifying epistemic communities in Indonesia is not an easy task, especially those in defense studies. One of the problems in determining them is the lack of experts. Due to the dominant role of the military in defense affairs for so many years, the number of civilian experts on this subject has been limited. Another problem is the fact that most of the so-called "experts" are retired officers and therefore to certain degree possessed an ideological attachment to their former group. Another "experts" are academics and journalists with a long history in defense affairs but without defense or military studies background. These are precisely the problem in identifying the first and second generations of epistemic community in defense studies in Indonesia.While the first generation of defense studies in Indonesia consists of retired officers, the second generation has already comprised of some civilian academics, such as Juwono Sudarsono and Salim Said, in addition to former officers, such as Agus Widjojo, (the late) Agus Wirahadikusuma, Susilo Bambang Yudhoyono, and

\footnotetext{
${ }^{5}$ Stone (2000) argues that the role of epistemic community is limited to acting as a clearing-house for information, advocacy working, and providing expertise on specialized issues to government agencies through their networks. She pointed out the importance of network or ties between academic and policy makers.

${ }^{6}$ However, this characterization is not always true. Academics relationship with funding institutions could easily make them partisan instead of neutral (Parmar, 2002).
}

Kusnadi Kardi. ${ }^{7}$ The third generation consists mostly of civilian scholars, but only a handful of them hold an academic degree in defense studies. ${ }^{8}$

In the early period of the reform, this third generation was the epistemic community in defense studies. Members of the second generation were either still active in the military or serving in the government. While these officers supported the reform from within TNI, the role of Sudarsono, ${ }^{9}$ who served as Minister of Defense during the early period of change, was particularly crucial in channeling the advice from members of the third generation. It intended to produce regulations related to defense affairs since most members of the third generation have personal ties with him. ${ }^{10}$ With Sudarsono served in government, these academics privileged access to decision makers.

Members of the third generation also have professional and personal links with military establishment and officers. CSIS has established close contacts with TNI as some of their experts, such as Sukma, Anggoro, and Prasetyono, taught at TNI's command college. Besides, Bhakti and Widjajanto also taught at the armed forces command school and had ties with numerous officers. Members of the third generation also have ties with government officials and members of the parliament through various connections. Lay, for example, is also known as a personal aide of Megawati. With such ties, they could diffuse the idea of SSR to both government and the military, something that the NGOs most often were lacking.

In addition to network with defense establishment and the political actors, the third generation also has linked with NGOs. Through their system with NGOs, the epistemic community in defense studies managed to spread the ideals of democratic governing to the public. NGO's role as a

\footnotetext{
${ }^{7}$ The former was professor in International Relations with the University of Indonesia, while the latter was professor in political science with University of Muhammadiyah Malang and now professor with National Defense University.

${ }^{8}$ This group of scholars consist both scholars and scholars-activists. They include Hari Prihartono (ProPatria Institute), Rizal Sukma (Center for Strategic and International Studies, CSIS), KusnantoAnggoro (formerly CSIS, currently independent scholar), EdyPrasetyono (formerly CSIS, currently University of Indonesia), Ikrar Nusa Bhakti (Indonesia's Institute of Science, LIPI), RiefqiMuna (LIPI), JaleswariPramodhawardani (LIPI), AnakAgung Banyu Perwita (formerly Parahyangan Catholic University, currently President University), Bob SugengHadiwinata (Parahyangan Catholic University), (the late) Munir (Commission for the Disappeared and Victims of Violence, Kontras), Andi Widjajanto (University of Indonesia), (the late) FajrulFalakh (GadjahMada University), Cornelis Lay (GadjahMada University), and BambangWidjojanto (Indonesia Legal Aid Institute, YLBHI). Of those academics, only Muna and Widjajanto hold academic degree in defense studies. Others are either political scientists, international relations scholars, or majoring in law. In addition to these scholars and scholar-activists, other names also involved in the WG but they were not frequent participants.

${ }^{9}$ One cannot neglect, off course the role of two other civilian Ministers of Defense during this period, i.e. Mahfud MD and Matori Abdul Jalil.

${ }^{10}$ Sukma and Sudarsono were both under the supervision of Professor Michael Leifer while attending $\mathrm{PhD}$ program - at different period of time-atLondon School of Economics. Anggoro, Bhakti, Prasetyono, and Widjajanto used to be Sudarsono's students during their undergraduate studies at University of Indonesia.
} 
pressure group to political process also enables the epistemic community to have two feet standing on two different camps.

To be able to gather regularly to discuss and build the framework of democratic governance of the defense policies, these academics grouped under the Pro Patria WG which was established in October 1999. Pro Patria WG held a series of meetings in various places to create a roadmap for military reform. This document argues that military change should not only be conducted through public pressure but also through a strategy of persuading the military and civilian government, to be able to work with epistemic community and NGOs in close coordination. It reflects the differing opinions of the participants of the meeting. The role of this WG in steering the agendas of military reform became apparent when the Ministry of Defense invited them in May 2000 to participate in the drafting of the Law of National Defense as well as the Law on the Armed Forces. Their involvement in the Ministry of Defense working group (kelompok kerja) gave alternative options for government policy.

These academics were not only involving in drafting the laws but also advocating these rules to the public as well as lobbying the parliament to pass these laws. Therefore, in addition to maintaining contacts with government officials and military officers, they also established ties with NGOs as pressure groups to the political process and with members of parliament. A sort of division of labors took place within the organization. Prihartono has been acknowledged by many as an excellent lobbyist with a close connection to several members of parliament, especially those that sit in Commission 1 (politics, security, and foreign policy affairs). Sukma and Muna were known as activists within the Muhammadiyah, the second largest Islamic group in Indonesia. Through this group, they have access to members of the Parliament with Muhammadiyah background. Lay provided access to, among other, Megawati through his personal tie with the Indonesia Democratic Party in Struggle (PDIP) chairwoman. Members of the third generation of defense studies also had personal links with NGOs. Pramodhawardani had long assisted numerous NGOs including Lespersi and IDSPS in their research and advocacy activities. The existence of scholar-activists within the group, such as Munir and Widjojanto, help the group to create a network with NGOs.

This group of academics, therefore, possessed a unique characteristic of ties with all stakeholders in the political process: government, military, parliament, and NGOs. Also, they also have academic capacity to introduce a framework for Indonesia's military reform. Through this network, they managed to influence the decision-making process from drafting the law, penetrating the law as urgent and essential agenda of parliament meeting, and pressuring the working of the political process through NGOs.

\section{CONCLUSION}

This paper has shown that epistemic community plays an influential role in setting the agenda and advancing military reform in Indonesia. This group of scholars establishes contacts with government and the military to get involved in the decision-making process. Also, the same group also establishes contacts with NGOs to assist them in pressing the government and the military to adopt reform agendas. Epistemic community in defense studies in Indonesia serves as a bridge between these two competing camps and manages to create an image of the neutral party. Unfortunately, their role in military reform was diminishing due to the lack of further academic interest in this issue. It was mainly because only a handful of them that had an academic interest in defense studies. Disagreements also prevail within this group over the next agendas of reform. Some suggest military modernization as the next important issue to be addressed while others take side with mainstream NGOs for further advancement of reform to address an issue such as human right abuses or military tribunal.

\section{ACKNOWLEDGEMENT}

The author would like to thank Wu Der-yuan, Sun Tsai-

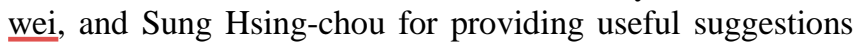
to the earlier version of this paper. The author would also like to thank The Directorate for Higher Education, Ministry of Research and Higher Education, Republic of Indonesia for funding this research. This research is part of the author's dissertation project on military reform in Indonesia. Finally, the author would also like to thank members of Anarchist WhatsApp Group for their discussions. Errors and omissions solely belong to the author.

\section{References}

[1]. African Union, SSR Trends and Challenges in Africa: a Partners' Summary of the first Africa Forum on SSR. Addis Ababa: Africa Union, 2014.

[2]. C. Lay, "The emerging of new democratic space: CSOs and parliament in post-Suharto Indonesia,” in PCD Journal, Vol. 5, No. 1, 2017, pp. 1-24.

[3]. DCAF, Developing a Security Sector Reform (SSR) Concept for the United Nations. Bratislava: DCAF, 2006.

[4]. D. Jenkins, "The evolution of Indonesian army doctrinal thinking: the concept of $\underline{d w i f u n q s i}$, , in Asian Journal of Social Science, Vol. 11, 1983, pp. 15-30.

[5]. D. Stone, "Non-governmental policy transfer: the strategies of independent policy institutes," in Governance, Vol. 13, No. 1, 2000, pp. 45-62.

[6]. D. Stone, "Introduction: global knowledge and advocacy networks” in Global Networks, Vol. 2, No. 1, 2002, pp. 1-11.

[7]. F. Heiduk, "From guardians to democrats? attempts to explain change and continuity in the civil-military relations of postauthoritarian Indonesia, Thailand, and the Philippines,” in The Pacific Review, Vol. 24, No. 2, 2011, pp. 249-271.

[8]. F, Scarpello, "Stifled development: the SSR-civil society organizations community in post-authoritarian Indonesia," in F. Heiduk, ed., Security sector reform in Southeast Asia: from 
policy to practice. London and NY: Palgrave Macmillan, 2014, pp. 131-158.

[9]. G. Faleg, "Between knowledge and power: epistemic communities and the emergence of security sector reform in the EU security architecture,” in European Security, Vol. 21, No. 2, 2012, pp. 161-184.

[10].I. Parmar, "American foundations and the development of international knowledge networks" in Global Networks, Vol. 2, No.1, 2002, pp. 13-30.

[11].J. Sugden, "Security sector reform: the role of epistemic community in UK," in Journal of Security Sector Management, Vol. 4, No. 4, 2006, pp. 1-20.

[12].LC. Sebastian and Iisgindarsah, "Taking Stock of Military Reform in Indonesia," in J. Ruland, MG. Manea and H. Born, eds., The Politics of Military Reform: Experiences from Indonesia and Nigeria. Berlin: Springer-Verlag, 2012, pp. 2956.

[13].LC. Sebastian and Iisgindarsah, "Assessing military reform in Indonesia," in Defense and Security Analysis, Vol. 29, No. 4, 2013, pp. 293-307.

[14].M. Mietzner, The politics of military reform in post-Suharto. Washington DC.: East-West Center, 2006.
[15].PM. Haas, "Introduction: epistemic communities and international policy coordination," in International Organization, Vol. 46, No. 1, 1992, p. 1-35.

[16].S. Said, "The political role of the Indonesian military: past, present, and future,” in Asian Journal of Social Science, Vol. 15, 1987, pp. 16-34.

[17].T. Lee, Defect or defend: military responses to popular protests in authoritarian Asia. Baltimore: John Hopkins University Press, 2016.

[18].TNI Headquarter, TNI Abad XXI: Redefinisi, Reposisi, danReaktualisasiPeran TNI dalamKehidupanBangsa [TNI in the Twenty First Century]. Jakarta: TNI Headquarter, 2001.

[19].R. Muna, "Local ownership and the experience of SSR in Indonesia," in T. Donais, ed., Local ownership and security sector reform. Zurich: Verlag, 2008, pp.233-252.

[20].R. Sukma, "The role of civil society in Indonesia's military reform," in J. Ruland, MG. Manea and H. Born, eds., Thepolitics of military reform: experiences from Indonesia and Nigeria. Berlin: Springer-Verlag, 2012, pp. 147-160. 